\title{
Performance Assessment of Native Tomato Genotypes to Late Blight Disease under Natural Epiphytotics
}

\author{
Raghuveer Singh ${ }^{1 *}$, N. Tiameren Ao ${ }^{2}$, Valenta Kangjam², \\ N. Bidyaleima Chanu ${ }^{3}$, L. Daiho ${ }^{2}$ and Susanta Banik ${ }^{2}$ \\ ${ }^{1}$ ICAR Research Complex for NEH Region, A.P. Centre, Basar-791101, \\ Arunachal Pradesh, India \\ ${ }^{2}$ Department of Plant Pathology, SASRD, Nagaland University, Medziphema Campus- \\ 797106, Nagaland, India \\ ${ }^{3}$ Department of Vegetable Science, College of Horticulture \& Forestry, CAU, Pasighat- \\ 791102, Arunachal Pradesh, India \\ *Corresponding author
}

\section{A B S T R A C T}

\section{Keywords}

Resistance, Late blight, Natural epiphytotics conditions, Native tomato genotypes

Article Info

Accepted:

17 October 2019

Available Online:

10 November 2019
A field study conducted to evaluate the native tomato genotypes for their resistance to late blight under natural epiphytotics conditions was carried out during 2017-18 and 2018-19. Twenty native tomato genotypes were collected from different tomato growing areas of Nagaland, Manipur and Arunachal Pradesh. Characteristics of tomato genotypes revealed that most of the collected genotypes were indeterminate in nature except Pusa Ruby (semi-determinate), Arka Rakshak, $\mathrm{F}_{1}$ hybrid (determinate) and $\mathrm{T}_{2}$ (determinate). The late blight disease severity was assessed visually on stems, leaves and fruits of all plants of each replication following scale 0-5, when total late blight infestation had occurred in the control plot. Disease severity data revealed that least PDI was recorded in $T_{3}$ (16.81) and $T_{17}$ (35.99) whereas highest PDI was recorded in Arka Rakshak, with 89.72. This experimental result revealed that most of the genotypes (20 genotypes) reacted as highly susceptible, while $\mathrm{T}_{3}(16.81 \mathrm{PDI}$ ) and $\mathrm{T}_{17}$ (35.99 PDI) was found resistant and tolerant respectively. These results clearly indicate that a good source of resistance to late blight is available in the genotype $T_{3}$ (cherry tomato). The resistant genotype thus obtained through this experiment shows a potential disease resistance trait contributor for tomato breeding against late blight disease.

\section{Introduction}

Late blight disease of tomato caused by Phytophthora infestans (Mont.) de Bary is devastating and wide spread in nature. It is an economically important disease of tomato worldwide including India (Son et al., 2008). Worldwide losses were estimated to $\$ 170$ 
billion annually and thus the pathogen was considered as a threat to global food security (Latijnhouwers et al., 2004; Wu et al., 2012). This disease can cause total destruction of all plant parts within a week or two when weather conditions are favourable (Agrios, 1997). And also could causes up to $100 \%$ crop losses if not controlled (HCDA, 1996). Yield losses up to $79 \%$ from late blight damage have been reported from India (Arora et al., 2014; Chowdappa et al., 2015). P. infestans has intensified its genetic variation in recent years, comprising isolates that are highly aggressive and highly virulent. Some isolates are resistant to phenylamides fungicide even (Goodwin et al., 1996). In order to subdue this trait, it is imperative to explore and find durable resistance. Several commercial tomato cultivars commonly grown in Nagaland are highly susceptible to late blight disease and show considerable yield losses under disease conducive conditions. The present investigation was carried out in Nagaland for the first time to determine the level of resistance in native tomato genotypes against late blight and its possible utilization in breeding programs to develop late blight disease resistant cultivars.

\section{Materials and Methods}

\section{Collection of tomato genotypes}

Ripened fruits of 20 native tomato genotypes were collected from different tomato growing areas of Nagaland, Manipur and Arunachal Pradesh. Known susceptible hybrid (Arka Rakshak, $F_{1}$ ) and susceptible variety (Pusa Ruby) seeds were also collected from IIHR, Bangalore and local market, Dimapur, respectively.

\section{Field experiment}

Field experiment was conducted during the tomato growing seasons (September-January) of 2017-18 and 2018-19 at the research farm of the Department of Plant Pathology, SASRD, Nagaland University, Medziphema Campus, Nagaland. The present experiment site is located in the foothills of Nagaland and situated at $25^{\circ} 45^{\prime} 45^{\prime \prime}$ North latitude and $93^{\circ}$ $51^{\prime} 45^{\prime \prime}$ East longitudes at an elevation of 310 $\mathrm{m}$ above mean sea level. The site is in a subhumid tropical with high humidity and moderate temperature $\left(12-32{ }^{\circ} \mathrm{C}\right)$, having moderate to high rainfall $(2000-3000 \mathrm{~mm})$ and R.H. of $70-80 \%$.

Two commercial susceptible cultivars of tomato, Pusa Ruby (semi-determinate type) and Arka Rakshak, $F_{1}$ (determinate type) were used in the experiment as control check.

Seeds of 22 genotypes were sown in the nursery beds (line sowing in spacing of row to row, $8 \mathrm{~cm}$ and seed to seed, $1 \mathrm{~cm}$ and depth, 1 $\mathrm{cm})$ on the second week of September and transplanted into the field on the second week of October during both years.

The field experiment was laid out in a randomized block design (RBD) with three replications (Gomez and Gomez 1984). Each plot was $1.95 \mathrm{~m} \times 2.0 \mathrm{~m}$ (raised plot) with three rows. Each row was spaced $65 \mathrm{~cm}$ apart. The distance from plot to plot was $50 \mathrm{~cm}$ and from plant to plant $50 \mathrm{~cm}$. Four plants per row and 12 plants per plot were maintained. Common cultural practices were followed during the cropping period.

\section{Fruit yield}

The yield of ripened fruits harvested at different dates from all plants was computed and their average per plant was noted in gram.

\section{Disease severity}

The disease severity was assessed visually on stems, leaves and fruits of all plants of each 
replication following scale 0-5 (Irzhansky and Cohen, 2006; table.1) when total late blight infestation had occurred in the control plot under natural epiphytotics conditions. The severity grades were converted into percentage disease index (PDI) for analysis (Wheeler, 1969).

PDI $=($ Sum of numerical rating $/$ No. of plant scored $\mathrm{x}$ maximum score in scale) $\mathrm{x} 100$.

\section{Statistical analysis}

Analysis of variance (ANOVA) was performed using the WASP 2.0 (WebAgrilStatPackage) software. None of the data was transformed.

\section{Results and Discussion}

\section{Characterization of tomato genotypes}

Characterization of 22 tomato genotypes and their collection locations are mentioned in table 2. Result revealed that most of the collected genotypes were indeterminate in nature except Pusa Ruby (semi-determinate), Arka Rakshak, $\mathrm{F}_{1}$ hybrid (determinate) and $\mathrm{T}_{2}$ (determinate).

Fruit shape of collected genotepes were oblong oval (Arka Rakshak $F_{1}$ ), flattish round (Pusa Ruby), small round cherry type $\left(\mathrm{T}_{2}, \mathrm{~T}_{3}\right.$, $\mathrm{T}_{4}, \mathrm{~T}_{9}, \mathrm{~T}_{16}, \mathrm{~T}_{17}, \mathrm{~T}_{18}, \mathrm{~T}_{19}$ and $\mathrm{T}_{20}$ ), round medium size $\left(\mathrm{T}_{5}\right)$, plum type $\left(\mathrm{T}_{6}, \mathrm{~T}_{10}, \mathrm{~T}_{11}\right.$ and $\left.\mathrm{T}_{14}\right)$, pointed small grape type $\left(\mathrm{T}_{7}\right)$, small round $\left(\mathrm{T}_{8}, \mathrm{~T}_{12}, \mathrm{~T}_{15}\right)$, round $\left(\mathrm{T}_{13}\right)$ and Heirloom $\left(\mathrm{T}_{21}\right)$.

Various research workers collected and characterized different genotypes of tomato, genotypes with spherical, smooth fruit especially John Bear, Main Crop, Sunshine, Victory and Matchless (Bondartzeva, 1926), which were reported to possess resistance to late blight of tomato. Yimchunger et al., (2018) also recorded different shapes of cherry tomato from Nagaland. They reported that shape among the traits like round, oblong, heart shape was noticed in different genotypes. They also mentioned that variations in different shape of fruit are influenced by the genetic makeup of the genotype.

\section{Fruit yield}

The yield of ripened fruits harvested at different dates from all plants was computed and their average per plant was recorded in gram. The data concerning to yield of tomato genotypes is depicted in table 3 .

The data revealed that Arka Rakshak, $F_{1}$ hybrid recorded highest yield $(3433.55 \mathrm{~g}$ plant $^{-1}$ and $105.65 \mathrm{t} \mathrm{ha}^{-1}$ ) followed by $\mathrm{T}_{5}$ (645.35 $\mathrm{g} \mathrm{plant}^{-1}$ and $19.85 \mathrm{t} \mathrm{ha}^{-1}$ ) and $\mathrm{T}_{21}$ (628.61 $\mathrm{g} \mathrm{plant}^{-1}$ and $19.34 \mathrm{t} \mathrm{ha}^{-1}$ ). The lowest yield was recorded in $\mathrm{T}_{19}$ with 268.15 g plant $^{-1}$ and $8.25 \mathrm{t} \mathrm{ha}^{-1}$.

These results are in conformity with the findings of Swaroop and Suryanarayana (2005), Ahmed et al., (2007), Doreswamy et al., (2011), Dar and Sharma (2011) and Narolia et al., (2012). Bhati, (2017) also evaluated tomato genotypes for growth, yield and quality traits under foothills condition of Nagaland. It is evident from this study that there was significant difference in yield attributes among various genotypes.

It was revealed from this study that yield per hectare profoundly affected by the genotypes. Maximum yield was recorded in genotype of TODVAR-8 (46.62 $\left.\mathrm{t} \mathrm{ha}^{-1}\right)$ followed by TODVAR-1 (33.14 $\left.\mathrm{t} \mathrm{ha}^{-1}\right)$. The minimum yield was recorded by genotype H-86 (12.41 t $\mathrm{ha}^{-1}$ ). 
Table.1 Rating scale (0-5) for the assessment of late blight disease severity in tomato

\begin{tabular}{|c|c|c|c|}
\hline Rating & PDI & Description & Reaction \\
\hline $\mathbf{0}$ & 0 & No visible symptoms apparent. & Immune \\
\hline $\mathbf{1}$ & $0.01-10$ & $\begin{array}{l}\text { A few minute lesions to about 10\% of the total leaf area } \\
\text { is blighted and usually confined to the 2 bottom leaves. }\end{array}$ & $\begin{array}{c}\text { Highly } \\
\text { resistant }\end{array}$ \\
\hline $\mathbf{2}$ & $10.01-25$ & Leaves on about 25\% of the total plant area are infected. & Resistant \\
\hline $\mathbf{3}$ & $25.01-40$ & Leaves on about 50\% of the total plant area are infected. & Tolerant \\
\hline $\mathbf{4}$ & $41.01-60$ & Leaves on about 75\% of the total plant area are infected. & Susceptible \\
\hline $\mathbf{5}$ & $>60.01$ & Leaves on whole plant are blighted and plant is dead. & $\begin{array}{c}\text { Highly } \\
\text { Susceptible }\end{array}$ \\
\hline
\end{tabular}

Table.2 Characterization of tomato genotypes and their collection location

\begin{tabular}{|c|c|c|c|c|c|c|}
\hline $\begin{array}{c}\text { Genotypes } \\
\text { Code }\end{array}$ & Type & Fruit type & $\begin{array}{l}\text { Growth } \\
\text { habits }\end{array}$ & Collected from & District & State \\
\hline $\mathbf{T}_{0}$ & $\begin{array}{c}\text { Arka } \\
\text { Rakshak, } \\
\mathrm{F}_{1} \text { hybrid }\end{array}$ & Oblong oval & Determinate & IIHR & Bangalore & Karnataka \\
\hline $\mathbf{T}_{1}$ & $\begin{array}{l}\text { Tomato cv. } \\
\text { Pusa Ruby }\end{array}$ & $\begin{array}{c}\text { Flattish } \\
\text { round }\end{array}$ & $\begin{array}{c}\text { Semi- } \\
\text { determinate }\end{array}$ & Local market & Dimapur & Nagaland \\
\hline $\mathbf{T}_{2}$ & $\begin{array}{l}\text { Cherry } \\
\text { tomato }\end{array}$ & Small round & Determinate & $\begin{array}{l}\text { Horticulture farm, } \\
\text { SASRD, } \\
\text { Medziphema }\end{array}$ & Dimapur & Nagaland \\
\hline $\mathbf{T}_{3}$ & $\begin{array}{l}\text { Cherry } \\
\text { tomato }\end{array}$ & Small round & Indeterminate & $\begin{array}{l}\text { Near C.V. Raman } \\
\text { Hostel, SASRD, } \\
\text { Medziphema }\end{array}$ & Dimapur & Nagaland \\
\hline $\mathbf{T}_{4}$ & $\begin{array}{l}\text { Cherry } \\
\text { tomato }\end{array}$ & Small round & Indeterminate & $\begin{array}{l}\text { Daily vegetable } \\
\text { market, Kohima } \\
\text { town }\end{array}$ & Kohima & Nagaland \\
\hline $\mathbf{T}_{5}$ & Tomato & $\begin{array}{c}\text { Round } \\
\text { medium size }\end{array}$ & Indeterminate & $\begin{array}{l}\text { Daily vegetable } \\
\text { market, Risethsi }\end{array}$ & Kiphre & Nagaland \\
\hline $\mathbf{T}_{6}$ & Tomato & Plum type & Indeterminate & $\begin{array}{l}\text { Daily vegetable } \\
\text { market, Merema }\end{array}$ & Kohima & Nagaland \\
\hline $\mathbf{T}_{7}$ & Tomato & $\begin{array}{l}\text { Pointed } \\
\text { small } \\
\text { Grape type }\end{array}$ & Indeterminate & $\begin{array}{l}\text { Daily vegetable } \\
\text { market, } \\
\text { Phekerkriema }\end{array}$ & Kohima & Nagaland \\
\hline $\mathbf{T}_{8}$ & Tomato & Small round & Indeterminate & $\begin{array}{l}\text { Daily vegetable } \\
\text { market, Merema }\end{array}$ & Kohima & Nagaland \\
\hline $\mathbf{T}_{9}$ & $\begin{array}{l}\text { Cherry } \\
\text { tomato }\end{array}$ & Small round & Indeterminate & $\begin{array}{l}\text { Daily vegetable } \\
\text { market, Tsiesema }\end{array}$ & Kohima & Nagaland \\
\hline$T_{10}$ & Tomato & Plum type & Indeterminate & $\begin{array}{l}\text { Daily vegetable } \\
\text { market, Wokha } \\
\text { town }\end{array}$ & Wokha & Nagaland \\
\hline
\end{tabular}




\begin{tabular}{|c|c|c|c|c|c|c|}
\hline $\mathbf{T}_{11}$ & Tomato & Plum type & Indeterminate & $\begin{array}{l}\text { Daily vegetable } \\
\text { market, Pfutsero }\end{array}$ & Phek & Nagaland \\
\hline$T_{12}$ & Tomato & Small round & Indeterminate & $\begin{array}{l}\text { Daily vegetable } \\
\text { market, Wokha } \\
\text { town }\end{array}$ & Wokha & Nagaland \\
\hline $\mathbf{T}_{13}$ & Tomato & Round & Indeterminate & $\begin{array}{l}\text { Daily vegetable } \\
\text { market, Pfutsero }\end{array}$ & Phek & Nagaland \\
\hline $\mathbf{T}_{14}$ & Tomato & Plum type & Indeterminate & $\begin{array}{l}\text { Daily vegetable } \\
\text { market, Kohima } \\
\text { town }\end{array}$ & Kohima & Nagaland \\
\hline $\mathbf{T}_{15}$ & Tomato & Small round & Indeterminate & $\begin{array}{l}\text { Daily vegetable } \\
\text { market, Kohima } \\
\text { town }\end{array}$ & Kohima & Nagaland \\
\hline $\mathbf{T}_{16}$ & $\begin{array}{l}\text { Cherry } \\
\text { tomato }\end{array}$ & Small round & Indeterminate & $\begin{array}{l}\text { Daily vegetable } \\
\text { market, Kohima } \\
\text { town }\end{array}$ & Kohima & Nagaland \\
\hline $\mathbf{T}_{17}$ & $\begin{array}{l}\text { Cherry } \\
\text { tomato }\end{array}$ & Small round & Indeterminate & $\begin{array}{l}\text { Daily vegetable } \\
\text { market, D' sector, } \\
\text { Itanagar }\end{array}$ & Papum Pare & $\begin{array}{c}\text { Arunachal } \\
\text { Pradesh }\end{array}$ \\
\hline$T_{18}$ & $\begin{array}{l}\text { Cherry } \\
\text { tomato }\end{array}$ & Small round & Indeterminate & $\begin{array}{l}\text { Daily vegetable } \\
\text { market, } \\
\text { Keishamthong }\end{array}$ & $\begin{array}{c}\text { Imphal } \\
\text { West }\end{array}$ & Manipur \\
\hline $\mathbf{T}_{19}$ & $\begin{array}{l}\text { Cherry } \\
\text { tomato }\end{array}$ & Small round & Indeterminate & $\begin{array}{l}\text { Daily vegetable } \\
\text { market, Moa gate }\end{array}$ & Senapati & Manipur \\
\hline $\mathbf{T}_{20}$ & $\begin{array}{l}\text { Cherry } \\
\text { tomato }\end{array}$ & Small round & Indeterminate & $\begin{array}{l}\text { Daily vegetable } \\
\text { market, Pisum } \\
\text { Oinam Leikai }\end{array}$ & $\begin{array}{c}\text { Imphal } \\
\text { West }\end{array}$ & Manipur \\
\hline $\mathbf{T}_{21}$ & Tomato & Heirloom & Indeterminate & $\begin{array}{l}\text { Daily vegetable } \\
\text { market, Risethsi }\end{array}$ & Kiphre & Nagaland \\
\hline
\end{tabular}


Table.3 Late blight disease severity, disease reaction and fruit yield of tomato genotypes under natural epiphytotics conditions

\begin{tabular}{|c|c|c|c|c|c|c|c|c|c|c|}
\hline \multirow[t]{2}{*}{ Genotypes } & \multicolumn{4}{|c|}{$\begin{array}{c}\text { Disease severity at } 124 \text { DAS } \\
(\text { PDI) }\end{array}$} & \multicolumn{3}{|c|}{$\begin{array}{l}\text { Fruit yield } \\
\left(\text { g plant }^{-1}\right)\end{array}$} & \multicolumn{3}{|c|}{$\begin{array}{c}\text { Calculated Fruit yield } \\
\left(\mathrm{t} \mathrm{ha}^{-1}\right)\end{array}$} \\
\hline & 2017-18 & 2018-19 & Pooled & $\begin{array}{l}\text { Disease } \\
\text { reaction }\end{array}$ & 2017-18 & 2018-19 & Pooled & 2017-18 & 2018-19 & Pooled \\
\hline $\mathbf{T}_{0}$ Arka Rakshak $\mathbf{F}_{1}$ (Control) & 92.22 & 87.22 & 89.72 & HS & 3450.44 & 3416.67 & 3433.55 & 106.17 & 105.13 & 105.65 \\
\hline $\mathrm{T}_{1}$ Pusa Ruby (Control) & 84.44 & 90.00 & 87.22 & HS & 275.56 & 271.33 & 273.44 & 08.48 & 08.35 & 08.41 \\
\hline $\mathbf{T}_{2}$ & 88.88 & 78.89 & 83.88 & HS & 327.50 & 276.67 & 302.08 & 10.08 & 08.51 & 09.29 \\
\hline $\mathbf{T}_{3}$ & 22.65 & 10.98 & 16.81 & $\mathbf{R}$ & 329.50 & 256.00 & 292.75 & 10.14 & 07.88 & 09.01 \\
\hline $\mathbf{T}_{4}$ & 47.01 & 79.18 & 63.09 & HS & 286.67 & 311.67 & 299.17 & 08.82 & 09.59 & 09.20 \\
\hline $\mathbf{T}_{5}$ & 53.87 & 83.94 & 68.90 & HS & 634.03 & 656.67 & 645.35 & 19.51 & 20.20 & 19.85 \\
\hline$T_{6}$ & 55.44 & 87.96 & 71.70 & HS & 418.73 & 393.33 & 406.03 & 12.88 & 12.10 & 12.49 \\
\hline $\mathbf{T}_{7}$ & 62.75 & 86.48 & 74.61 & HS & 504.63 & 423.33 & 463.98 & 15.53 & 13.02 & 14.27 \\
\hline $\mathbf{T}_{8}$ & 58.63 & 68.00 & 63.31 & HS & 541.41 & 446.67 & 494.04 & 16.66 & 13.74 & 15.20 \\
\hline $\mathbf{T}_{9}$ & 50.73 & 78.57 & 64.65 & HS & 371.69 & 343.33 & 357.51 & 11.44 & 10.56 & 11.00 \\
\hline $\mathbf{T}_{10}$ & 67.97 & 79.76 & 73.86 & HS & 514.78 & 463.33 & 489.05 & 15.84 & 14.26 & 15.05 \\
\hline$T_{11}$ & 73.96 & 81.11 & 77.53 & HS & 340.75 & 355.33 & 348.04 & 10.48 & 10.93 & 10.70 \\
\hline$T_{12}$ & 76.39 & 86.46 & 81.42 & HS & 462.86 & 408.67 & 435.76 & 14.24 & 12.57 & 13.40 \\
\hline$T_{13}$ & 67.39 & 80.22 & 73.80 & HS & 339.41 & 285.67 & 312.54 & 10.44 & 08.79 & 09.61 \\
\hline$T_{14}$ & 60.00 & 87.53 & 73.76 & HS & 300.67 & 291.33 & 296.00 & 09.25 & 08.96 & 09.10 \\
\hline$T_{15}$ & 66.07 & 76.94 & 71.50 & HS & 331.81 & 306.67 & 319.24 & 10.21 & 09.43 & 09.82 \\
\hline $\mathbf{T}_{16}$ & 53.52 & 79.35 & 66.43 & HS & 334.61 & 266.67 & 300.64 & 10.29 & 08.20 & 09.24 \\
\hline $\mathbf{T}_{17}$ & 38.33 & 33.65 & 35.99 & $\mathbf{T}$ & 238.85 & 325.33 & 282.09 & 07.35 & 10.01 & 08.68 \\
\hline$T_{18}$ & 59.61 & 78.34 & 68.97 & HS & 254.82 & 293.33 & 274.07 & 07.84 & 09.02 & 08.43 \\
\hline$T_{19}$ & 53.70 & 78.70 & 66.20 & HS & 282.97 & 253.33 & 268.15 & 08.71 & 07.79 & 08.25 \\
\hline $\mathbf{T}_{20}$ & 51.59 & 81.11 & 66.35 & HS & 284.02 & 283.33 & 283.67 & 08.74 & 08.72 & 08.73 \\
\hline $\mathbf{T}_{21}$ & 71.67 & 81.20 & 76.43 & HS & 693.89 & 563.33 & 628.61 & 21.35 & 17.33 & 19.34 \\
\hline SEm \pm & 4.06 & 3.30 & 2.52 & - & 57.25 & 38.44 & 36.03 & 1.76 & 1.19 & 1.11 \\
\hline C.V. (\%) & 11.41 & 7.50 & 6.33 & & 18.49 & 13.05 & 12.25 & 18.94 & 13.35 & 12.26 \\
\hline $\mathrm{CD}(\mathrm{P}=\mathbf{0 . 0 5})$ & 11.59 & 9.42 & 7.19 & - & 163.40 & 109.70 & 102.83 & 5.03 & 3.41 & 3.17 \\
\hline
\end{tabular}

$\mathbf{H R}=$ Highly resistant, $\mathbf{R}=$ Resistant, $\mathbf{T}=$ Tolerant, $\mathbf{S}=$ Susceptible and $\mathbf{H S}=$ Highly susceptible. 
Fig.1 Late blight disease reaction of tomato genotypes, $\mathrm{T}_{0}$ (Arka Rakshak $\mathrm{F}_{1}$, highly susceptible) and $\mathrm{T}_{3}$ (Cherry tomato, resistance)

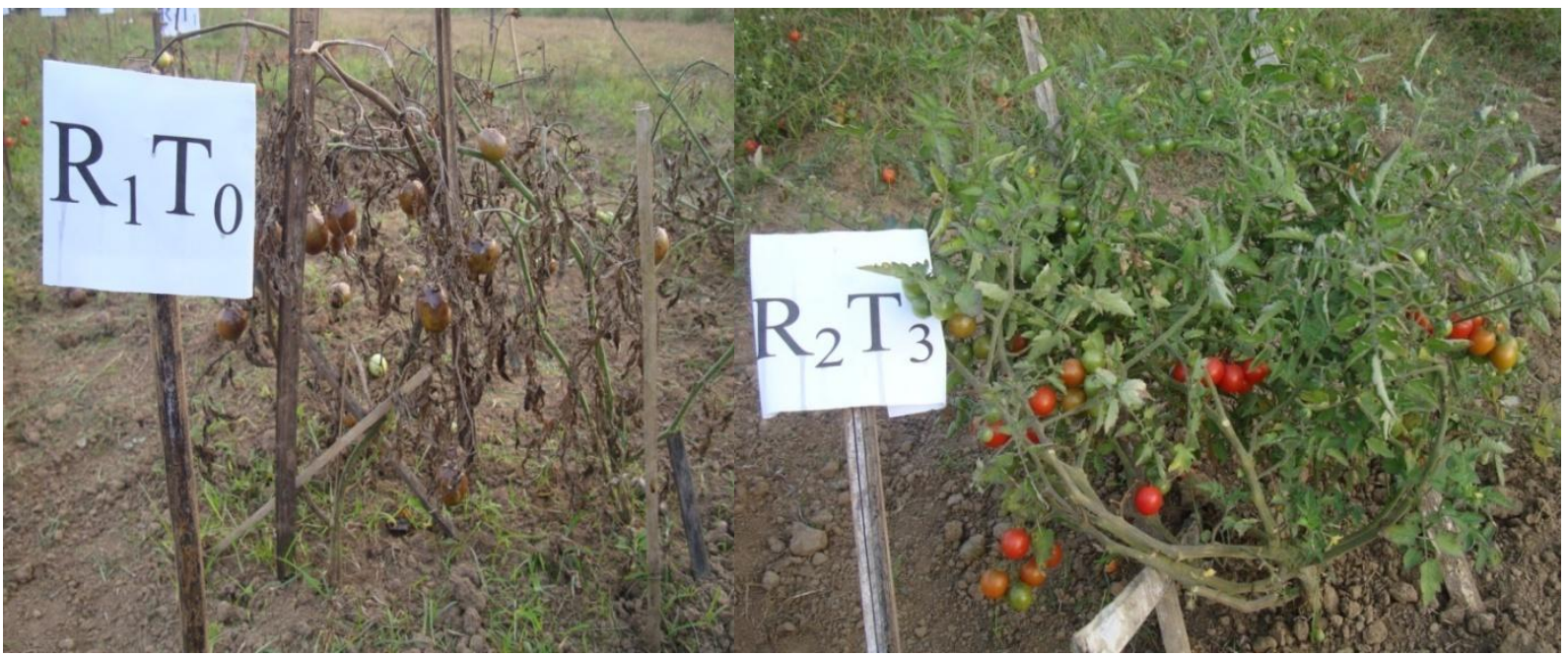

Fig.2 Late blight disease severity (Pooled PDI) of tomato genotypes under natural epiphytotics conditions

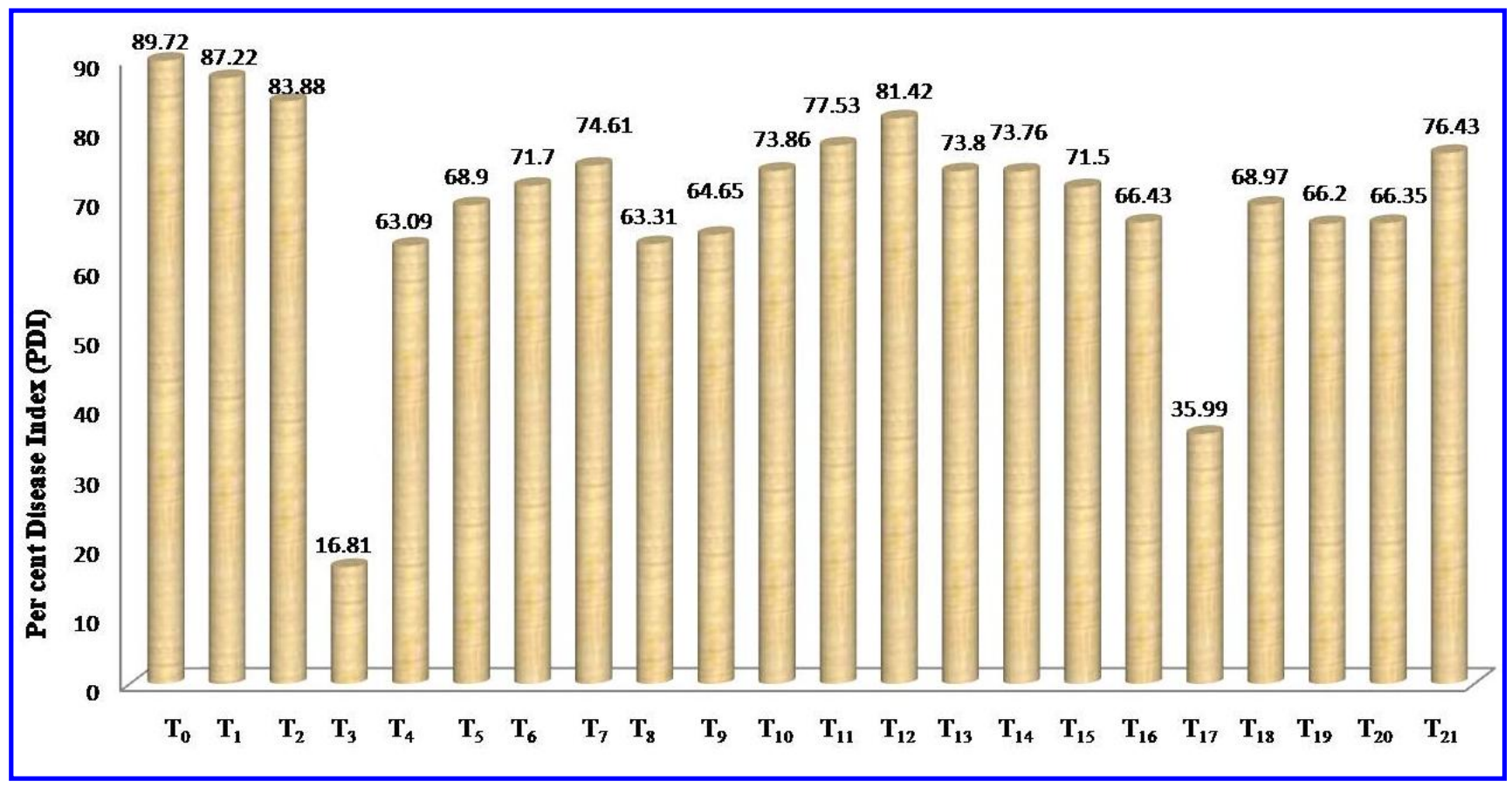

\section{Disease severity}

In all, 22 genotypes were screened against the late blight disease under natural epiphtotic condions in field and disease reaction was recorded at 124 DAS and presented in table 3.
The data of disease severity revealed that least PDI was recorded in $\mathrm{T}_{3}(16.81)$ and $\mathrm{T}_{17}$ (35.99) whereas highest PDI was recorded in Arka Rakshak, $F_{1}$ control with 89.72 (Fig. 2). 
This experimental result revealed that most of the genotypes (20 genotypes) reacted as highly susceptible, while $\mathrm{T}_{3}$ (16.81 PDI) and $\mathrm{T}_{17}$ (35.99 PDI) was found resistant and tolerant respectively under natural epiphytotics conditions. These results clearly indicate that a good source of resistance to late blight is available in the genotype $\mathrm{T}_{3}$ (Fig. 1). The resistant genotype thus obtained through this experiment shows a potential disease resistance trait contributor for tomato breeding against late blight disease.

This is in line with the findings of Islam et al., (2001) who evaluated 15 advanced lines of tomato against late blight under natural epiphytotics conditions. The highest late blight severity was found in V-215 and V-52 and the lowest in V-378. Two lines were found resistant (V-259 and V-426), two moderately resistant (V-385 and V-187), two tolerant (V422 and V-282), four moderately susceptible (V-378, V-138, V-258 and BARI-10), three were susceptible (V-330, V-201 and Manik) and two highly susceptible (V-52 and V-215), but none were found highly resistant. Khalid et al., (2012) also evaluated 82 tomato genotypes against late blight using whole plant assays. None of the test genotypes were immune or highly resistant. The overall screening results indicate that TMS-2 is a good source of resistance and it can be useful for the development of tomato hybrid cultivars resistant to late blight.

\section{References}

Agrios, G. N. 1997. Plant Pathology. $4^{\text {th }}$ Ed., Academic Press, New York. 248- 278.

Ahemad, M. and Kibret, M. 2014, Mechanisms and applications of plant growth promoting rhizobacteria: Current perspective. Journal of King Saud University Science. 26: 1-20.

Arora, R. K., Sharma, S. and Singh, B. P. 2014. Late blight disease of potato and its management. Potato Journal. 41(1): 16-40.

Bhati, V. 2017. Evaluation of tomato genotypes for growth, yield and quality traits under foothills condition of Nagaland, India. International Journal of Microbiology and Applied Sciences. 6 (3): 1645-1649.

Bondartzeva, M.V.N. 1926. Phytophthora infestans (Mont.) de Bary on tomatoes. Morbi Plantarum. 15 (1): 27.

Chowdappa, P., Kumar, N. B. J., Madhura, S., Myers, K. L., Fry, W. E. and Cooke, D. L. 2015. Severe outbreaks of late blight on potato and tomato in south India caused by recent changes in the Phytophthora infestans population. Plant Pathology. 64: 191-199.

Dar, R.A. and Sharma, J.P. 2011. Genetic variability studies of yield and quality traits in tomato. International Journal of Plant Breeding and Genetics. 1-7.

Doreswamy, C., Channakeshava, S. and Niranjanamurthy. 2011. Performance of different chilli genotypes in southern dry zone of Karnataka. Journal of Environment and Ecology. 29 (3): 1229-1231.

Gomez, K.A. and Gomez, A.A. 1984. Statistical procedures for agricultural research. $2^{\text {nd }}$ Ed. Wiley Interscience Publication, John Wiley and Sons, IRRI, Philippines. 480.

Goodwin, S.B., Sujkowski, L.S. and Fry, W.E. 1996. Widespread distribution and probable origin of resistance to metalaxyl in clonal genotypes of Phytophthora infestans in the United States and Western Canada. Phytopathology. 86 (7): 793-800.

HCDA. 1996. Horti. Crops Development Authority. Horticulture News. No. 5, 12.

Irzhansky, I. and Cohen, Y. 2006. Inheritance of resistance against Phytophthora infestans in Lycopersicon 
pimpinellifolium L3707. Euphytica. 149: 309-316.

Islam, N., Pramanik, B.K., Khokon, M.A.R. and Ashrafuzzaman, M. 2001. Performance assessment of tomato advanced lines to late blight and early blight under natural epiphytotics. Pakistan Journal of Biological Sciences. 4 (11): 1361-1363.

Khalid, P. A., Muhammad, Y. S., Muhammad, A., Shaukat, A., Nighat, S. and Muhammad, T. E. 2012. Resistance of Solanum spp. to Phytophthora infestans evaluated in the detached-leaf and whole-plant assays. Pakistan Journal of Botany. 44 (3): 1141-1146.

Latijnhouwers, M., Ligterink, W., Vleeshouwers, V. G., VanWest, P. and Govers, F. 2004. A Ga subunit controls zoospore mobility and virulence in the potato late blight pathogen Phytophthora infestans. Molecular Microbiology. 51: 925-936.

Narolia, R.K., Reddy, R.V.S.K. and Sujatha, M. 2012. Genertic architecture of yield and quality in tomato. Agricultural Science and Digest. 3 (4): 281-285.

Son, S. W., Kim, H. Y., Choi, G. J., Lim, H.
K., Jang, K. S., Lee, S. O., Sung, N. D. and Kim, J. C. 2008. Bikaverin and fusaric acid from Fusarium oxysporum show antinomycete activity against $P$. infestans. Journal of Applied Microbiology. 104: 692-698.

Swaroop, K. and Suryanarayana, M.A. 2005. Evaluation of tomato varieties and lines for growth, yield, quality and bacterial wilt resistance under coastal tropical condition of the Andaman Islands. Tropical Agriculture. 82: 294299.

Wheeler, B. J. 1969. An Introduction to Plant Diseases. John Wiley and Sons, Ltd. 510.

Wu, Y., Jiang, J. and Gui, C. 2012. Low genetic diversity of Phytophthora infestans population in potato in north China. African Journal of Biotechnology. 11 (90): 15636-15642.

Yimchunger, T.L., Sarkar, A. and Kanaujia, S.P. 2018. Evaluation of different genotypes of cherry tomato (Solanum lycopersicum var. cerasiforme) under foothill condition of Nagaland. Annals of Plant and Soil Research. 20 (3): 228-232.

\section{How to cite this article:}

Raghuveer Singh, N. Tiameren Ao, Valenta Kangjam, N. Bidyaleima Chanu, L. Daiho and Susanta Banik. 2019. Performance Assessment of Native Tomato Genotypes to Late Blight Disease under Natural Epiphytotics. Int.J.Curr.Microbiol.App.Sci. 8(11): 1923-1931. doi: https://doi.org/10.20546/ijcmas.2019.811.226 